\title{
Behavior of Ten Chironja Clones at Three Sites. II. Fruit Quality ${ }^{1}$
}

\author{
A. Pérez, E. Boneta, E. Pérez, and J. Green ${ }^{2}$
}

\begin{abstract}
Ten chironja clonal varieties were studied at the Isabela, Corozal, and Adjuntas Substations with respect to their fruit qualities.

The total soluble solids at Isabela and Corozal was $11 \%$, significantly lower than that at Adjuntas, (15\%). The total soluble solids increased as the tree became older. The citric acid content at the Isabela and Corozal Substations was $0.6 \%$, significantly lower than that at Adjuntas, $(0.9 \%)$. Acid content varied significantly between years and Substations. The Brix/acid ratio at Adjuntas was 17 , significantly lower than that at Isabela and Corozal, where it was 19. The citric acid content varied among the different clonal varieties. The fruits harvested during 1971 were rounder than those of 1972 , which were elongated. The fruits at Adjuntas were smaller and had a significantly lower percentage of juice than those at Isabela and Corozal, which were equal in size and juice content. Fruits at Isabela had significantly lower peel percentage than those at Corozal and Adjuntas, which did not differ. Fruits produced at Isabela had significantly more seeds than those at Corozal and Adjuntas. The number of seeds per fruit varied significantly among years and Substations. The 2-3 and 3-6 clonal varieties had 11 and 14 seconds respectively, significantly fewer than those all other clones. Therefore, these two clones should be propagated by growers who prefer chironja fruits with fewer seeds.
\end{abstract}

\section{INTRODUCTION}

The chironja is a new type of citrus fruit with good fruit qualities. Its high juice content, good flavor, low acidity, big size, and appearance make this fruit very appealing. Moscoso (6) describes it as a unique fruit for its color, size and external appearance. Díaz (4) reported that chironja fruits can be stored under refrigeration at $7^{\circ} \mathrm{C}$ up to 70 days without losing their quality.

Since fruit quality may vary within varieties $(5,6)$ and species $(2,8)$, this research was initiated to study the fruit qualities in 10 chironja clonal varieties that were grafted on sour orange rootstock.

\section{MATERIALS AND METHODS}

The procedure of this research as to orchard establishment, management and experimental design was described previously (7).

When the trees came into a heavy production ( 6 years old), 15 fruits were collected at a height of $2 \mathrm{~m}$, around the canopy of each tree. Fruits showing above $50 \%$ yellow color were sampled. From this sample, 5 fruits

${ }^{1}$ Manuscript submitted to Editorial Board July 9, 1979.

${ }^{2}$ Horticulturist, Assistant Horticulturist, Instructor, and Research Assistant respectively, Agricultural Experiment Station, College of Agricultural Sciences, Mayagüez Campus, University of Puerto Rico, Mayagüez and Río Piedras, P.R. 
were analyzed for soluble solids, citric acid and pH, with A.O.A.C. (1) methods. The Brix/acid ratio was determined by dividing Brix by the citric acid content.

The following attributes were measured in the other 10 fruits: fruit diameter to height ratio $(\mathrm{D} / \mathrm{H})$ to determine the fruit shape of each clone; and weight and percentage of juice per fruit. The 10 fruits per tree were weighed, cut into halves and the juice extracted with an electric juicer. The juice was weighed and the mean percentage obtained. After the juice was extracted, the peel weight and percentage were determined.

\section{RESULTS AND DISCUSSION}

Table 1 shows that the soluble solids content increased significantly from 1970 to 1973, an increase with tree age. Tree size and fruit production also increased with age (1), but age was accompanied with a reduction in fruit size.

Table 1 also shows that citric acid increased significantly from 1970 to 1971; it did not change in 1972, but was reduced in 1973. The content of

TABLE 1.-Soluble solids, citric acid content (\%) and soluble solids/citric acid ratio during the years 1970 through 1973 of chironjas harvested at Isabela,

Corozal and Adjuntas

\begin{tabular}{|c|c|c|c|c|}
\hline \multirow{2}{*}{ Year } & \multicolumn{3}{|c|}{ Substations } & \multirow{2}{*}{ Mean } \\
\hline & Isabela & Corozal & Adjuntas & \\
\hline \multicolumn{5}{|c|}{ Soluble solids } \\
\hline 1970 & 11.1 & 10.2 & 10.0 & $10.4 \mathrm{a}^{1}$ \\
\hline 1971 & 11.8 & 12.1 & 13.0 & $12.3 \mathrm{~b}$ \\
\hline 1972 & 11.0 & 11.2 & 14.9 & $12.4 \mathrm{~b}$ \\
\hline 1973 & 11.4 & 10.5 & 21.7 & $14.5 \mathrm{c}$ \\
\hline Mean & $11.3 \mathrm{a}$ & $11.0 \mathrm{a}$ & $14.9 \mathrm{~b}$ & 12.4 \\
\hline \multicolumn{5}{|c|}{ Citric acid } \\
\hline 1970 & 0.76 & 0.49 & 0.50 & $0.58 \mathrm{a}$ \\
\hline 1971 & 0.73 & 0.72 & 0.99 & $0.82 \mathrm{c}$ \\
\hline 1972 & 0.48 & 0.70 & 1.18 & $0.79 \mathrm{c}$ \\
\hline 1973 & 0.55 & 0.52 & 1.08 & $0.72 \mathrm{~b}$ \\
\hline Mean & $0.63 \mathrm{a}$ & $0.61 \mathrm{a}$ & $0.94 \mathrm{~b}$ & 0.73 \\
\hline \multicolumn{5}{|c|}{ Soluble solids/citric acid ratio } \\
\hline $1970^{\circ}$ & 14.6 & 20.8 & 20.0 & $18.5 \mathrm{~b}$ \\
\hline 1971 & 16.2 & 16.8 & 13.1 & $15.4 \mathrm{a}$ \\
\hline 1972 & 22.9 & 16.0 & 12.6 & $17.2 \mathrm{~b}$ \\
\hline 1973 & 20.7 & 20.2 & 20.1 & $20.3 \mathrm{c}$ \\
\hline Mean & $18.6 \mathrm{~b}$ & $18.5 \mathrm{~b}$ & $16.5 \mathrm{a}$ & 17.8 \\
\hline
\end{tabular}

${ }^{1}$ Means in column and row followed by the same letter do not differ significantly at the 0.01 probability level. 
soluble solids and citric acid of Isabela and Corozal were similar; both were significantly lower than those at Adjuntas. The soluble solids to citric acid ratios were equal at Isabela and Corozal, but significantly lower at Adjuntas. The variation of this fruit attribute was great from year to year.

Table 2 shows that the citric acid content varied significantly in the 10 chironja clones indicating that some varieties may be propagated for either their high or low acid content.

TABLE 2.-Citric acid percentage in the 10 chironja clones during 1970 through 1973

\begin{tabular}{cccccc}
\hline & \multicolumn{3}{c}{ Year } & \multirow{2}{*}{ Mean } \\
\cline { 2 - 4 } Clones & 1970 & 1971 & 1972 & 1973 & \\
\hline $2-3$ & 0.57 & 0.79 & 0.76 & 0.77 & $0.72 \mathrm{a}^{\prime}$ \\
$3-6$ & 0.57 & 0.77 & 0.79 & 0.66 & $0.70 \mathrm{a}$ \\
$2-4$ & 0.61 & 0.77 & 0.81 & 0.77 & $0.74 \mathrm{~b}$ \\
$4-11$ & 0.61 & 0.91 & 0.86 & 0.71 & $0.77 \mathrm{~d}$ \\
$3-8$ & 0.58 & 0.77 & 0.76 & 0.77 & $0.72 \mathrm{a}$ \\
$3-4$ & 0.58 & 0.90 & 0.75 & 0.77 & $0.75 \mathrm{c}$ \\
$6-12$ & 0.60 & 0.86 & 0.85 & 0.69 & $0.75 \mathrm{c}$ \\
$2-7$ & 0.59 & 0.81 & 0.82 & 0.69 & $0.73 \mathrm{a}$ \\
$5-7$ & 0.57 & 0.83 & 0.76 & 0.63 & $0.70 \mathrm{a}$ \\
$3-3$ & 0.56 & 0.75 & 0.72 & 0.74 & $0.69 \mathrm{a}$ \\
Mean & $0.58 \mathrm{a}$ & $0.82 \mathrm{c}$ & $0.79 \mathrm{c}$ & $0.72 \mathrm{~b}$ & 0.73 \\
\hline
\end{tabular}

${ }^{1}$ Means in column and row followed by the same letter do not differ significantly at the 0.01 probability level.

TABle 3.-Juice pH of chironjas harvested at Isabela, Corozal and Adjuntas during 1970 through 1973

\begin{tabular}{ccccc}
\hline & \multicolumn{3}{c}{ Substation } & \multirow{2}{*}{ Mean } \\
\cline { 2 - 4 } & Isabela & Corozal & Adjuntas & \\
\hline 1970 & 3.57 & 3.96 & 3.75 & $3.76 \mathrm{c}^{1}$ \\
1971 & 3.51 & 3.58 & 3.45 & $3.51 \mathrm{a}$ \\
1972 & 3.63 & 3.39 & 3.37 & $3.46 \mathrm{a}$ \\
1973 & 3.84 & 3.08 & 3.90 & $3.61 \mathrm{~b}$ \\
Mean & $3.64 \mathrm{~b}$ & $3.50 \mathrm{a}$ & $3.62 \mathrm{~b}$ & 3.59 \\
\hline
\end{tabular}

'Means in column and row followed by the same letter do not differ significantly at the 0.01 probability level.

The $\mathrm{pH}$ did not vary between clones. Table 3 shows that this fruit attribute varied significantly from year to year, and was about equal at the Isabela and the Adjuntas Substations, where the fruits had a significantly higher $\mathrm{pH}$ than those at Corozal.

Fruit shapes were obtained by measuring the diameter to height (D/ $\mathrm{H})$ ratio. Table 4 shows that there is a statistically significant variation of this fruit attribute due to years and clones. If we consider that round 
fruits have a ratio of 1.00 , it may be said that the fruits harvested during 1971 were rounder than those of 1972, which were elongated, and that in some clones the fruits were more elongated than in others. A highly statistical significant difference was also found between Substation fruits of each shape. The $\mathrm{D} / \mathrm{H}$ ratio for the Corozal fruits was 0.94 , for the

TABLE 4.-Diameter to height $(D / H)$ ratio of fruits of the 10 chironja clones in 1971 and 1972

\begin{tabular}{cccc}
\hline \multirow{2}{*}{ Clone } & \multicolumn{3}{c}{ Year } \\
\cline { 2 - 3 } & 1971 & 1972 & Mean \\
\hline $2-3$ & 1.00 & 0.92 & $0.96 \mathrm{a}^{1}$ \\
$3-6$ & 1.01 & 0.92 & $0.97 \mathrm{~b}$ \\
$2-4$ & 1.01 & 0.94 & $0.98 \mathrm{c}$ \\
$4-11$ & 0.99 & 0.94 & $0.97 \mathrm{~b}$ \\
$3-8$ & 1.00 & 0.94 & $0.97 \mathrm{~b}$ \\
$3-4$ & 1.01 & 0.96 & $0.99 \mathrm{~d}$ \\
$6-12$ & 1.00 & 0.94 & $0.97 \mathrm{~b}$ \\
$2-7$ & 1.00 & 0.93 & $0.97 \mathrm{~b}$ \\
$5-7$ & 0.99 & 0.93 & $0.96 \mathrm{a}$ \\
$3-3$ & 0.99 & 0.93 & $0.96 \mathrm{a}$ \\
Mean & $1.00 \mathrm{~b}$ & $0.93 \mathrm{a}$ & 0.97 \\
\hline
\end{tabular}

${ }^{1}$ Means in column and row followed by the same letter do not differ significantly at the 0.05 probability level.

TABLE 5.-Weight (g) and juice percentage per fruit in 1970, 1971 and 1972 at Isabela, Corozal and Adjuntas

\begin{tabular}{ccccc}
\hline \multirow{2}{*}{ Year } & \multicolumn{3}{c}{ Substation } & \multirow{2}{*}{ Mean } \\
\cline { 2 - 3 } & Isabela & Corozal & Adjuntas & \\
& \multicolumn{4}{c}{ Juice weight per fruit } \\
1970 & 157 & 232 & 183 & $191 \mathrm{~b}^{1}$ \\
1971 & 234 & 237 & 213 & $228 \mathrm{c}$ \\
1972 & 218 & 147 & 150 & $172 \mathrm{a}$ \\
Mean & $203 \mathrm{~b}$ & $205 \mathrm{~b}$ & $182 \mathrm{a}$ & 197 \\
& \multicolumn{4}{c}{ Juice percentage per fruit } \\
1970 & 34 & 44 & 37 & $38 \mathrm{a}$ \\
1971 & 53 & 55 & 52 & $53 \mathrm{~b}$ \\
1972 & 50 & 38 & 46 & $45 \mathrm{a}$ \\
Mean & $46 \mathrm{a}$ & $46 \mathrm{a}$ & $45 \mathrm{a}$ & 45 \\
\hline
\end{tabular}

${ }^{1}$ Means in column and row followed by the same letter do not differ significantly at the $5 \%$ and $1 \%$ probability levels, respectively.

Isabela, 0.96 and 0.99 for the Adjuntas fruits. These differences were significant at the 0.01 level. This indicates that the Adjuntas fruits were rounder; those of Corozal, elongated; and those of Isabela, intermediate.

Table 5 shows that the juice weight per fruit varied significantly as to years and Substations and that juice percentage varied in regard to years only. This variance suggests that when studying the effect of years and 
locations on juice weight and the percentage of juice per fruit, juice weight is a better measurement than juice percentage. Neither the juice weight and percentage per fruit in the 10 clones was significantly different.

Table 6 shows weight and percentage of peel per fruit. Chironjas produced in Adjuntas and Corozal had similar percentages and weight of peel. In both Substations peel weight was significantly higher than in fruits at Isabela.

TABLE 6.-Weight (g) and percentage of peel per fruit in 1970, 1971 and 1972 at the Isabela, Corozal and Adjuntas Substations

\begin{tabular}{ccccc}
\hline \multirow{4}{*}{ Year } & \multicolumn{3}{c}{ Substation } & Mean \\
\cline { 2 - 3 } & Isabela & Corozal & Adjuntas & \\
\hline & \multicolumn{3}{c}{ Weight } \\
1970 & 93.9 & 113.5 & 101.1 & $102.8 \mathrm{a}$ \\
1971 & 132.3 & 133.4 & 133.4 & $133.0 \mathrm{c}$ \\
1972 & 100.9 & 125.3 & 127.0 & $117.7 \mathrm{~b}$ \\
Mean & $109.0 \mathrm{a}$ & $124.1 \mathrm{~b}$ & $120.5 \mathrm{~b}$ & 117.9 \\
& & Percentage & & \\
1970 & 20.3 & 21.8 & 20.5 & $20.9 \mathrm{a}$ \\
1971 & 30.0 & 30.9 & 32.5 & $31.1 \mathrm{~b}$ \\
1972 & 23.2 & 32.4 & 38.8 & $30.7 \mathrm{~b}$ \\
Mean & $24.4 \mathrm{a}$ & $27.8 \mathrm{~b}$ & $29.4 \mathrm{~b}$ & 27.1 \\
\hline
\end{tabular}

${ }^{1}$ Means in column and row followed by the same letter do not differ significantly at the 0.01 probability level.

TABLE 7.-Mean number of seeds per fruit of the 10 chironja clones in 1970 and 1971

\begin{tabular}{cccc}
\hline & \multicolumn{2}{c}{ Year } & Mean \\
\cline { 2 - 3 } & 1970 & 1971 & $11 \mathrm{a}^{1}$ \\
$2-3$ & 11 & 12 & $14 \mathrm{~b}$ \\
$3-6$ & 13 & 16 & $21 \mathrm{~d}$ \\
$2-4$ & 21 & 21 & $23 \mathrm{f}$ \\
$4-11$ & 23 & 23 & $20 \mathrm{c}$ \\
$3-8$ & 20 & 20 & $22 \mathrm{e}$ \\
$3-4$ & 23 & 21 & $22 \mathrm{e}$ \\
$6-12$ & 22 & 22 & $20 \mathrm{c}$ \\
$2-7$ & 20 & 21 & $22 \mathrm{e}$ \\
$5-7$ & 23 & 22 & $21 \mathrm{~d}$ \\
$3-3$ & 20 & 22 & 20 \\
Mean & $19 \mathrm{a}$ & $20 \mathrm{~b}$ & \\
\hline
\end{tabular}

'Means in column and row followed by the same letter do not differ significantly at the 0.01 and 0.05 probability level, respectively.

This difference indicates that fruits in Isabela could not be well adapted to peel processing since peel production is significantly lower than that of fruits of the other two Substations.

Tables 7 and 8 show the number of seeds per fruit of the 10 chironja clones, and the number produced during 2 years at the three Substations, 
respectively. Table 7 shows that clones $2-3$ and 3-6 had the significantly lowest number of seeds. The number of seeds in the former clone was significantly lower than that of the latter, indicating that chironjas with even lower number of seeds may be borne by clone 2-3. The fruits of clone 2-3 were significantly smaller than those of the other clones (7). This result agrees with those of Cameron et al. (3) and Stewart et al. (9), who reported that the number of seeds is directly correlated with fruit size in Valencia orange and Clementine mandarine. Table 8 indicates that there is a variation within years and Substations for the number of seeds per fruit. The interaction between year and Substation was highly significant and was more pronounced at the Corozal and the Adjuntas Substation, where fruits had equal numbers of seeds, and significantly fewer seeds than those obtained in Isabela.

TABLE 8.-Mean number of seeds per fruit at Isabela, Corozal and Adjuntas in 1971 and 1972

\begin{tabular}{ccccc}
\hline \multirow{2}{*}{ Year } & \multicolumn{3}{c}{ Substation } & \multirow{2}{*}{ Mean } \\
\cline { 2 - 4 } & Isabela & Corozal & Adjuntas & \\
\hline 1971 & 22 & 17 & 20 & $19 \mathrm{a}^{1}$ \\
1972 & 21 & 20 & 18 & $20 \mathrm{~b}$ \\
Mean & $21 \mathrm{~b}$ & $18 \mathrm{a}$ & $19 \mathrm{a}$ & 20 \\
\hline
\end{tabular}

${ }^{1}$ Means followed by the same letter in column and row do not differ significantly at the 0.05 and 0.01 probability level, respectively.

\section{RESUMEN}

En experimentos Ilevados a cabo en Isabela, Corozal y Adjuntas, donde se estudió el comportamiento de 10 variedades clonales de chironja con respecto a la calidad de sus frutos se encontró lo siguiente: Los sólidos solubles totales en Isabela y Corozal fueron de 11\% solamente, mientras que en Adjuntas fueron significativamente más elevados (15\%). Los sólidos solubles totales aumentaron significativamente de $10 \%$ en 1970 a $15 \%$ en 1973 , lo cual puede deberse a que el tamaño de la fruta se achicó en los árboles más viejos y por lo tanto los azúcares en la fruta se concentraron.

El contenido de ácido cítrico de las frutas de Isabela y Corozal fue de $0.6 \%$; en ambas fue significativamente menor que en Adjuntas, donde fue $0.9 \%$. El contenido de este ácido en las frutas fue influido por años y por localidades. La relación entre los sólidos solubles y el ácido cítrico en las Subestaciones de Isabela y Corozal fue 19, siendo significativamente mayor que el de Adjuntas, donde fue 17. El contenido de ácido cítrico varió significativamente entre las diferentes variedades clonales.

Las frutas cosechadas en 1971 fueron redondas mientras que las cosechadas en 1972 fueron alargadas. Las cosechadas en Adjuntas 
fueron las que arrojaron un contenido de jugo significativamente más bajo, y fueron mucho más pequeñas que las de Isabela y Corozal, las cuales no fueron diferentes en tamaño y contenido de jugo.

En Isabela tuvieron significativamente menos cáscara que en Corozal y Adjuntas, entre las cuales no hubo diferencia. Las producidas en Isabela tuvieron 21 semillas, lo cual fue significativamente más alto que en Corozal, con 18 y en Adjuntas con 19. El número de semillas por fruta varió entre años y entre Subestaciones. Las variedades clonales $2-$ 3 y 3-6 tuvieron 11 y 14 semillas respectivamente, lo cual fue significativamente más bajo que en las otras.

\section{LITERATURE CITED}

1. Assoc. Off. Agri. Chem., 1970. Official methods of analysis, Washington D.C.

2. Bitters, W.P. and Batchelor, L.D., 1951. Effect of rootstocks ont he size of orange fruits, Proc. Am. Soc. Hort. Sci. 57: 133.

3. Cameron, J.W., Cole, Jr., D., and Naver, E.M., 1960. Fruit size in relation to seed number in the Valencia orange and some other citrus varieties, Proc. Am. Soc. Hort.Sci. 76: 170-80.

4. Diaz, N., 1976. Effect of storage at $45^{\circ} \mathrm{F}\left(7^{\circ} \mathrm{C}\right)$ on keeping quality of five chironja clones, J. Agri. Univ. P.R. 60 (3): 348:68.

5. Gardner, F.E. and Reece, P.C., 1960. Evaluation of 28 Navel orange varieties in Florida, Proc. Fla. State Hort. Soc., 73:23-8.

6. Moscoso, C.G., 1976. La Chironja: una nueva fruta puertorriqueña, Esta. Exp. Agri., Univ. P.R. Bol. 248.

7. Pérez, A., R. Bosque, Pérez, E., and Green, J., 1980. Behavior of ten chironja clones at the Isabela, Corozal and Adjuntas Substations: I Growth and Yield. J. Agri. Univ. P.R. 64 (3):

8. Sinclair, W.B., 1961. The orange, its biochemistry and physiology, Berkeley, Univ. Div. Agri. Sci.

9. Stewart, I., Bridges, G.D., Pieringer, A.P., and Wheaton, T.A., 1975. Rohde Red Valencia an orange selection with improved juice colo, Proc. Fla. State Hort. Soc. 8:17-27. 